University of Pennsylvania Carey Law School

Penn Carey Law: Legal Scholarship Repository

Faculty Scholarship at Penn Carey Law

$1-1-2012$

\title{
A Dialogue on the Costs and Benefits of Automatic Stays for Derivatives and Repurchase Agreements
}

Darrell Duffie

Stanford University

David A. Skeel Jr.

University of Pennsylvania Carey Law School

Follow this and additional works at: https://scholarship.law.upenn.edu/faculty_scholarship

Part of the Banking and Finance Law Commons, Bankruptcy Law Commons, Business Law, Public Responsibility, and Ethics Commons, Business Organizations Law Commons, Corporate Finance Commons, and the Finance and Financial Management Commons

\section{Repository Citation}

Duffie, Darrell and Skeel, David A. Jr., "A Dialogue on the Costs and Benefits of Automatic Stays for Derivatives and Repurchase Agreements" (2012). Faculty Scholarship at Penn Carey Law. 386. https://scholarship.law.upenn.edu/faculty_scholarship/386

This Book Chapter is brought to you for free and open access by Penn Carey Law: Legal Scholarship Repository. It has been accepted for inclusion in Faculty Scholarship at Penn Carey Law by an authorized administrator of Penn Carey Law: Legal Scholarship Repository. For more information, please contact PennlawIR@law.upenn.edu. 


\title{
A Dialogue on the Costs and Benefits of Automatic Stays for Derivatives and Repurchase Agreements*
}

\author{
Darrell Duffie and David Skeel
}

November, 2011; revised, January, 2012

\section{Introduction}

For nearly two years, the two of us have had a running discussion of the costs and benefits of automatic stays for qualified financial contracts (QFCs), particularly those held by systemically important major dealer banks. ${ }^{1}$ Prominent among these QFCs are over-the-counter (OTC) derivatives and repurchase agreements (repos). Several large U.S. financial institutions now have aggregate notional positions in OTC derivatives exceeding $\$ 50$ trillion. ${ }^{2}$ Every business day, the broker-dealer affiliates of these same large banks roll over $\$ 100$ billion or more of new repo financing of their securities inventories. As we will explain, in the event that such a large financial institution files for bankruptcy without automatic stays on these massive positions in derivatives and repos, its QFC counterparties would derive what amounts to significant additional priority over other creditors. The advantages and disadvantages of this priority, which we will summarize, have been a matter of significant debate for the past decade, particularly since the 2008 crisis.

We agree with each other on the nature of the advantages and disadvantages of stays on QFCs, but in some cases have weighed them differently in reaching policy judgments, such as what sorts of financial institutions and QFCs should be exempted from these stays. We hope that this report on our dialogue may shed some useful light on these tradeoffs.

After some background on QFCs and automatic stays, we provide our joint analysis of the costs and benefits of stays on the QFCs, with a focus on systemically important financial institutions, including the special case of central market utilities.

\footnotetext{
${ }^{*}$ Duffie is at the Graduate School of Business, Stanford University. Skeel is at the University of Pennsylvania Law School. We are grateful for helpful exchanges with Marnoch Aston, Andrew Crockett, Doug Diamond, Richard Herring, Tom Jackson, Bill Kroener, David Mengle, Martin Oehmke, Ken Scott, Penfield Starke, Kimberly Summe, John Taylor, Paul Tucker, and Bruce Tuckman. The views expressed here, however, are entirely our own, and need not be held by any of these commenters. Duffie has potential conflicts of interest that may be reviewed at his web page (www.stanford.edu/ duffie/). Among these, he has been retained as a consultant by the estate of Lehman Brothers Holdings Inc. on matters potentially related to the subject of this paper.

${ }^{1} \mathrm{QFC}$ is the term used for these contracts in banking regulation. The treatment in bankruptcy is similar in many respects, but the bankruptcy law does not have an umbrella term corresponding to QFC. It uses separate terms for different categories of QFCs, such as swap, repurchase agreement, securities contract, and forward contract.

2 The latest available data can be found in quarterly reports of the Office of the Comptroller of the Currency.
} 
Following this, we state our respective policy conclusions. Briefly speaking, we both believe that repos (and certain closely related QFCs) that are backed by liquid securities should be exempt from automatic stays, or receive an effectively similar treatment. Repos backed by illiquid assets, on the other hand, should not be given this safe harbor. We both believe that derivatives that have not been centrally cleared should be subject to automatic stays. One of us believes that stays should also apply to cleared derivatives. The other author favors an exemption of cleared derivatives from stays, except in the case of a failure of a regulated central clearing party.

\section{Background}

When a firm files for bankruptcy in the United States, a stay immediately and automatically goes into effect. ${ }^{3}$ The stay prohibits a creditor from seizing or selling collateral, from starting or continuing litigation against the debtor, or taking other action to collect what the creditor is owed. In general, the stay has the purpose of giving the debtor breathing space and halting the destructive "grab race" that might otherwise ensue as creditors seek to collect what they are owed before the debtor's assets are exhausted. Creditors can negotiate with the debtor and other creditors and can otherwise participate in the bankruptcy case. But they cannot terminate contracts or engage in ordinary collection activities without first obtaining the approval of the bankruptcy court. As a result of a series of legislative amendments in the three decades since the current framework was enacted in 1978, U.S. bankruptcy law now exempts qualified financial contracts (QFCs) from the automatic stay and several other core bankruptcy provisions (one of which, the preference provision, also will figure in our discussion below). The exempted contracts include: swaps, which are broadly defined to include OTC derivatives and a wide variety of other contracts, as well as "any agreement or transaction that is similar" to any of the listed contracts; repurchase agreements; securities contracts; forward contracts; and commodity contracts. ${ }^{4}$

Derivatives are financial contracts whose payments are typically linked to the prices of other financial instruments. They are used mainly for speculation and hedging. Derivatives that are traded over the counter have an elaborate contractual regime of counterparty credit risk management that is based on collateralization of counterparty exposures and on the close-out netting of gains and losses on contracts with the same counterparty. An early-termination close-out is triggered by events

\footnotetext{
311 U.S.C. $\S 362(a)$.

4 The definitions can be found in 11 U.S.C. $\S 101$ (53B)(swap agreement); 11 U.S.C. $\S$ 101(47)(repurchase agreements); 11 U.S.C. $\$ 101$ (25)(forward contract); 11 U.S.C. $\S$ 741(7)(securities contract); 11 U.S.C. $\$ 761$ (commodity contract). "Financial participant," another key term, is defined in $\S 101(22 \mathrm{~A})$.
} 
such as failure to pay, a change of control, and, because of the exemption from the stay and related provisions, bankruptcy. ${ }^{5}$

A repurchase agreement, commonly known as a "repo," is a contractual arrangement under which a firm sells securities and simultaneously commits to repurchase them at a pre-arranged price on a given future date. Repos are used, among other purposes, to finance the purchase of securities. For this application, the cash received in the opening-leg sale of securities can be viewed as the cash proceeds of a loan; the repurchase price can be viewed as the loan payback amount. The securities act as collateral to the effective loan. The repo counterparty, who is the effective cash lender, holds the title to the securities during the term of the repo and can therefore protect itself from the failure of the effective borrower through its rights to the securities in lieu of receiving the cash back on the repo. Repos are also the most common vehicle for taking short positions in fixed-income securities. To create such a short, the counterparty immediately sells the securities that it receives at the opening leg of the repo. In order to meet its obligation to return the securities at the termination date of the repo, the counterparty buys them at that time in the spot market. The counterparty thus profits from any decline in the market value of the securities during the term of the repo. Shorts are used for both hedging and speculative motives.

As we have mentioned, the most important examples of QFCs for large dealer banks are OTC derivatives and repos. Securities lending agreements are essentially the same as repos in most economic and legal respects, and are commonly used to create short positions in equities. ${ }^{6}$ Our remarks concerning repos can generally be applied to securities lending agreements, another prominent form of QFC.

The special treatment for QFCs, often called a "safe harbor," has been justified on a variety of grounds. ${ }^{7}$ If derivatives and repos were subject to the automatic stay, safe-harbor proponents have argued, then a debtor's failure could have a "domino effect," taking other market participants down with it. For example, a counterparty that had entered into a large derivatives contract with the debtor to hedge its business risks might find itself suddenly and unexpectedly unhedged. With

5 Derivatives and other QFCs also are exempt from bankruptcy's anti-ipso facto provisions. An ipso facto clause is a provision that defines the debtor's bankruptcy or insolvency as an event of default and thus grounds for terminating the contact. Derivatives counterparties can thus terminate their contracts when the debtor files for bankruptcy, see 11 U.S.C. $§ 559$ (exempting repos from bankruptcy's invalidation of ipso facto clauses), § 560 (exempting swaps), § 561 (exempting netting agreements), whereas ordinary contract creditors cannot. See 11 U.S.C. § 541(c); § 365(e).

6 For an extended analysis of the similarities between repos and securities lending, see Andre Ruchin, Can Securities Lending Transactions Substitute for Repurchase Agreement Transactions, 128 BANKING L.J. 450 (2011).

7 The arguments summarized in this paragraph are described in greater detail in David Skeel \& Thomas Jackson, Transaction Consistency and the New Finance in Bankruptcy, COLUM. L. REV. (forthcoming 2012). 
a stay, it could not cancel its contract. It might not be able enter into a new hedging contract on similar terms with another firm, and if it did enter such a replacement position, it would run the risk of having too large a total derivatives position if its original contract was unexpectedly assumed by the debtor's estate. The counterparty might also be harmed by the delay in obtaining access to its collateral, or if the market moved against it while the debtor was in bankruptcy. Any delay in the counterparty's ability to terminate its derivatives with the debtor could therefore destabilize the counterparty, and might even undermine market confidence more generally. ${ }^{8}$ Safe-harbor advocates have also warned about the ill effects of "cherry picking." ${ }^{9}$ With a stay, a debtor could assume the contracts that are "in the money," while rejecting its bad contracts and relegating the counterparty's claim for damages to general unsecured status. The debtor's bankruptcy could therefore cripple certain counterparties, perhaps destabilizing the entire underlying market.

While QFCs are generally exempted from the automatic stay in bankruptcy, this exemption does not apply to the failure resolution process for regulated banks administered by the Federal Deposit Insurance Corporation (FDIC). Once the Department of the Treasury initiates such a resolution, and the FDIC takes over as receiver, an automatic stay on QFCs is in place for up to 24 hours. During this oneday period, the FDIC has the right to, among other actions, transfer QFCs to a bridge financial institution or reject them. A rejected QFC that is not secured by collateral would be treated as a general unsecured claim, and relegated to the payout given to unsecured claims. If the rejected QFC were collateralized, on the other hand, the counterparty could immediately sell the collateral, reducing the amount it was owed; any deficiency would then be treated as a general unsecured claim. Historically, rather than rejecting QFCs selectively, the FDIC has usually assigned QFCs en masse to a bridge financial institution.

Title II of The Dodd-Frank Act introduced new resolution rules for systemically important financial institutions (SIFIs). Although SIFIs are not precluded from filing for bankruptcy, regulators can put a SIFI into the new resolution framework if, among other conditions, it is in default or in danger of default and its failure could create systemic problems. ${ }^{10}$ The new Title-II rules institute what amounts to a brief stay on QFCs that is in essence the same as the one-day FDIC stay applied to regulated banks. During the stay period of such a resolution, counterparties are not permitted to invoke the ipso facto clauses in their contracts. ${ }^{11}$ In particular, they cannot terminate contracts until 5 p.m. of the day

8 These arguments correspond to what is sometimes described as counterparty contagion and a confidence crisis.

9 See, e.g., John C. Dugan, Derivatives: Netting, Insolvency, and End Users, 112 BANKING L.J. 638, 640 (1995), emphasizing “cherry-picking” concern.

10 The resolution requirements are set forth in Dodd-Frank Act § 203(b).

11 As noted earlier, an ipso facto clause is a provision that defines the debtor's bankruptcy or insolvency as an event of default and thus grounds for terminating the contact. Ipso facto clauses are standard provisions in OTC derivatives and repos. 
after the receivership is commenced. By that time, however, the contracts may have been rejected by the FDIC, or may have been transferred to a bridge financial institution or another acquirer of some portion of the debtor's business, without a right by the counterparty to terminate.

It is too early to tell which specific institutions will be subject to Title-II resolutions. Major non-bank users of financial QFCs include central clearing parties for OTC derivatives, large hedge funds, large insurance firms, and large asset managers. Some of these could be designated as systemically important under the Dodd-Frank Act, which would make them candidates for Title-II resolution in the event they fall into financial distress. ${ }^{12}$ The Title-II resolution process is to be administered by the FDIC in essentially the same manner as the resolution process for regulated banks.

Thus, U.S. law now applies what amounts to a one-plus day automatic stay on QFCs held by banks, large bank holding companies, and designated systemically important non-bank financial firms. Central clearing parties for derivatives are, however, exempted from some aspects of the stay, whether or not they are designated as systemically important, under a special provision of the Dodd-Frank Act. We will come back to this limited exemption. As for insurance firms, indefinite stays can be applied during insolvency processes in some venues, such as the state of New York. ${ }^{13}$ In the European Union, a series of "settlement-finality" EU Directives offers exemption from normal bankruptcy hold-ups for QFC-like transactions. ${ }^{14}$

There has not yet been a "live-ammo" test of the application of stays on QFCs on the scale of the largest dealer banks or other major holders of OTC derivatives and repos. This absence of experience covers the history of FDIC bank resolutions, the Title-II process of Dodd-Frank, as well as resolution procedures used outside of

12 Title I of the Dodd-Frank Act authorizes regulators to designate non-bank financial institutions a systemically important, and automatically puts banks with $\$ 50$ billion or more in assets in this category. These institutions are subject to a variety of regulations, including higher capital requirements, that do not apply to other institutions. The Dodd-Frank Act does not make this status a prerequisite for Title II resolution, but it does require regulators to conclude that a financial institution's default could have systemic consequences as a prerequisite to putting the institution into resolution. Dodd-Frank Act $§ 203(b)(2)$.

13 For the case of insurance firms domiciled in New York State, see the discussion of Section 7419 of the New York Laws in "How Safe is the Harbor? Navigating Restructurings Involving Insurance Company and Other Specialized Counterparties, CDSs, Mortgage Repos, Biofuels Contracts and Obscure Derivatives," ABA Business Bankruptcy Committee, Chapter 11 Subcommittee, September 25, 2008, Scottsdale, Arizona.

14 In "Systemic Liquidity Risk and Bankruptcy Exceptions," Centre for Economic Policy Research, Policy Insight Number 52, October, 2010, Enrico Perotti lists the relevant EU Directives. He writes that "The complete list is as follows: (EU Financial Collateral Directive of 6 June 2002 (OJ L 168/43), the EU Settlement Finality Directive in 19 May 1998 on settlement finality in payment and securities settlement systems (OJ L 166/45), Directive 2009/44/EC of 6 May 2009 amending Directive 98/26/EC on settlement finality in payment and securities settlement systems, and Directive 2002/47/ EC on financial collateral arrangements as regards linked systems and credit claims." 
the U.S. Thus, some of our discussion of the failure consequences of stays is necessarily speculative. We have some experience with bankruptcy safe harbors, that is, with the absence of a stay, most dramatically in the Lehman Brothers case, but even here significant questions remain.

We will explain how the behavior of systemically important financial institutions and their counterparties, both before and during failure, depends markedly on the presence or absence of an automatic stay. As a result, the existence of a stay has a direct and large impact on participants in these contracts, and may also have a major impact on financial market stability and thus the wider economy.

\section{Key Costs and Benefits}

One of the reasons the two of us have spent so much time discussing safe harbors for QFCs over the past two years is that this exemption from the stay has costs and benefits that are both extremely significant. Potential losses that are purely transfers from one market participant to another are not on their own significant to policy analysis, but are important whenever there are net social costs, for example through systemic risk or deadweight frictional distress costs to the debtor or its counterparties. The social costs and benefits of these stays have been studied for some time. ${ }^{15}$

QFC safe harbors could potentially raise social costs through five major channels: (1) lowering the incentives of counterparties to monitor the firm; (2) increasing the ability of, or incentive for, the firm to become too big to fail, with the attendant moral hazard of relying on bailouts; (3) inefficient substitution away from more traditional forms of financing; (4) increasing the market impact of collateral fire sales; and (5) lowering the incentives of a distressed firm to file for bankruptcy in a timely manner. We now discuss these channels, and later turn to the similarly extensive potential benefits of the safe harbor.

The first and second channels are closely linked. As argued by Roe (2010) and others, the safe-harbor exemption from stays reduces a QFC counterparty's incentive to monitor the debtor. Technically, the exemption does not give a derivatives or repo counterparty higher priority than other creditors, but by freeing a counterparty from the strictures of the stay that apply to most creditors, it has a similar effect. This protection diminishes the counterparty's incentive to carefully screen the debtor before entering into a QFC, in order to avoid exposure to weak

\footnotetext{
15 For recent analyses, see Mark J. Roe, The Derivatives Market's Payment Priorities as Financial Crisis Accelerator, 63 STAN. L. REV. 539 (2011); Robert R. Bliss \& George G. Kaufman, Derivatives and Systematic Risk: Netting, Collateral and Closeout, 2 J. FIN. STAB. 55-70 (2006); Patrick Bolton \& Martin Oehmke Should Derivatives be Senior?, Columbia University working paper, May 11, 2011; and Franklin R. Edwards \& Edward R. Morrison Derivatives and the Bankruptcy Code: Why the Special Treatment?, 22 YALE J. REG. 91-122 (2005).
} 
debtors. The safe harbor also lowers the benefit of monitoring the debtor's financial condition during the term of the contract. Monitoring is beneficial to the extent that it disciplines the debtor from taking risks that are excessive or otherwise inefficient. Lowering the risk of the debtor's failure is a social benefit because of the deadweight costs of failure, such as legal expenses, lost franchise value, and potential knock-on costs to the financial system.

Even with a safe harbor, the incentive to monitor does not disappear, because a counterparty cannot be certain that it will be made whole in bankruptcy if it is not fully collateralized. This was made clear in the case of Lehman's bankruptcy, which in some instances caused losses to derivatives counterparties above and beyond those associated with the normal performance of their derivatives positions with Lehman. ${ }^{16}$ As explained by Summe (2011), Lehman's large-bank counterparties have recently settled about $\$ 22$ billion in claims against Lehman for their losses on OTC derivatives, receiving between 27.9 cents and 39 cents per dollar of claim. From the reporting period following the failure of Lehman in 2008 until June 2011, U.S. bank holding companies have experienced approximately $\$ 12$ billion in additional losses due to derivatives counterparty default, according to statistics compiled by the Office of the Comptroller of the Currency (OCC). ${ }^{17}$ This belies the notion that QFC counterparties can walk away at default, paid in full, leaving only non-QFC creditors to bear the costs of bankruptcy. A significant quantity of OTC derivatives claims against Lehman remain unsettled to this day, over three years after the bankruptcy. Nevertheless, the incentive for derivatives counterparties to monitor is certainly reduced significantly by the safe harbor. A similar dilution in monitoring incentives applies to repos.

The argument that safe-harbor prioritization lowers the monitoring incentives of one class of claimants relative to another mirrors familiar considerations that apply to ordinary senior and junior unsecured creditors. Creditor prioritization involves a well-studied efficiency tradeoff, with the higher priority creditor potentially decreasing and the lower priority creditor increasing its monitoring. Indeed, banks have sometimes been encouraged by regulation to issue subordinated bonds in order to improve monitoring. The argument was that the associated dilution of the monitoring incentives of senior creditors would be more than offset by the increased monitoring effectiveness of subordinated creditors. They would become the "canary in the coal mine." Likewise, the fact that the safe harbor lowers the seniority of ordinary creditors relative to QFC claimants should improve the effectiveness of monitoring by senior unsecured creditors, at least for a

16 Kimberly Summe, "An Examination of Lehman Brothers' Derivatives Portfolio Post-Bankruptcy and Whether Dodd-Frank Would Have Made Any Difference," April 2011.

17 See “OCC's Quarterly Report on Bank Trading and Derivatives Activities, Second Quarter 2011," at page 18. 
firm that is not too big to fail. ${ }^{18}$ (We consider the too-big-to-fail effect shortly.) Thus, the fact that the safe harbor has monitoring implications does not on its own imply a net loss of monitoring efficiency. In any case, if the loss of monitoring efficiency associated with the safe harbor involves a sufficiently large expected cost to a given firm, that firm could simply choose not to use derivatives. It could commit to avoid them by its charter or through debt covenants.

This tradeoff argument does not apply, however, to the extent that the firm fails to internalize the costs of its failure to others. For example, if there is reason to believe that the debtor will be "bailed out" by the government before it collapses, the monitoring incentive of senior unsecured creditors is reduced. The likelihood of a bailout, moreover, grows with the size of the debtor's derivatives and repo books, because of the systemic risk associated with large positions in these QFCs. A safe harbor from the automatic stay therefore allows, or even encourages, a dealer bank to operate bigger derivatives and securities businesses. Thus, the safe harbor contributes to the "too-big-to-fail" moral hazard. This, the incentive to become toobig-to-fail, is a second cost of the safe harbors from the automatic stay.

The third cost stems from the fact that the safe harbor may make repos and derivatives a cheaper source of financing than alternatives such as traditional secured loans. As evidence of this, a major expansion of the safe harbor for repos in 2005 may have contributed to a sharp increase in repo financing shortly before the 2008 crisis. ${ }^{19}$ That a safe harbor increases the incentive to use one form of credit over another need not, on its own, be problematic. Basic Modigliani-Miller principles predict that a debtor that chooses to save money on cheaper financing with derivatives and repos would simply pay more for traditional debt financing, because investors in bonds and loans who lose priority will simply charge higher interest rates in compensation for the associated increase in expected default losses. Absent frictions, there is nothing problematic about this. Even with frictions, a firm rationally chooses its all-in lowest-cost form of financing. If extensive use of QFCs raises the firm's expected net frictional distress costs for itself and its creditors, in total, the firm would reduce its use of QFCs. (The costs to its counterparties and creditors is priced into the terms of its contracts, and thus born by the debtor as well.) On the other hand, as with monitoring incentives, the firm does not consider the systemic costs of its financing policy. So, does the safe harbor cause a substitution away from other forms of financing that would have lower systemic risk costs? We now turn to a consideration of this question.

Repos typically have shorter terms than traditional secured loans. The majority of repo financing is overnight. As a result, repo financing is relatively

18 Some creditors, such as bank depositors, may be less likely to adjust their monitoring in response to the QFC priority. But these creditors do not predominate with the large financial institutions under consideration here.

${ }_{19}$ These changes extended the safe harbor to repos using non-cash collateral such as mortgage-backed securities. See, e.g., Stephen J. Lubben, The Bankruptcy Code Without Safe Harbors, 84 AM. BANKR. L.J. 123, 138 (2010). 
fragile. If repo lenders lose confidence in the debtor and refuse to roll over a debtor's repos, the debtor can lose access to this financing almost instantly, as occurred with the failures of Bear Stearns and Lehman. ${ }^{20}$ With an automatic stay for repos, cash lenders might be less interested in offering so much short-term credit in the form of repos. Absent the safe harbor, some lenders such as money market funds that are subject to rules requiring ready access to their funds might also face regulatory obstacles to the use of repos. Would the next best alternative form of financing be less subject to a run? It does seem likely that an automatic stay on repos would lower the attractiveness of short-term repos that are backed by relatively illiquid assets, such as collateralized debt obligations (CDOs). As argued by Gorton and Metrick (2011), cash lenders may have viewed CDO-backed repos as a close substitute for cash deposits. ${ }^{21}$ The safe harbor for QFCs enhances the ability of cash investors in these repos to quickly extract themselves at low expected cost from their credit exposures to weakening borrowers. Absent the safe harbor, a significant amount of pre-crisis repo borrowing backed by CDOs might not have occurred. This would likely have lowered some of the damaging systemic impact of the financial crisis. Going forward, absent the safe harbor, some of the borrowing by banks that is backed by relatively illiquid assets such as mortgages might have longer maturities, and perhaps occur in the form of covered bonds rather than repos. This could further lower the fragility of bank financing.

Fourth, in addition to promoting the financial fragility of systemically important borrowers, the safe harbor for repos increases the potential for large and destabilizing collateral fire sales. With no stay, repo cash lenders often have an incentive, and in some cases a regulatory requirement, ${ }^{22}$ to sell the collateralizing securities they hold against repos as soon as possible after the failure of the debtor. The safe harbor, which provides an incentive for the use of short-term repo-based financing, might therefore lead to less stable markets. ${ }^{23}$ The less liquid are the collateralizing securities, the greater is the adverse impact of fire sales on the underlying market.

Finally, the absence of a stay may diminish the willingness of the managers of a troubled financial institution to voluntarily file for bankruptcy. If the managers cannot stop counterparties from terminating their contracts and selling collateral, they are less likely to initiate insolvency proceedings, because bankruptcy does not give them a mechanism for delaying termination. This makes it more likely that

\footnotetext{
20 See, for example, Darrell Duffie, How Big Banks Fail - and What to Do About It, Princeton University Press, 2010.

21 See Gary Gorton and Andrew Metrick, "Securitized Banking and the Run on Repo," 2011 Working Paper, Yale University, forthcoming in Journal of Financial Economics.

22 Under Rule 2a7, money market funds are not permitted to invest in many of the types of securities that back the repos in which they invest cash. For a discussion of the associated systemic risk, see A. Copeland, D. Duffie, A. Martin, and S. McLaughlin, "Policy Issues in the Design of Tri-Party Repo Markets," Working Paper, Stanford University and Federal Reserve Bank of New York, July, 2011.

23 See, e.g., Kenneth Ayotte \& David A. Skeel, Jr., Bankruptcy or Bailouts?, 35 J. CORP. L. 469 (2009)(discussing bankruptcy's benefits and the effect of the safe harbors).
} 
regulators will be left to initiate insolvency proceedings. Regulator-initiated insolvency could be more costly. Regulators have less information than the managers about the most efficient time to initiate bankruptcy. Regulators may also hesitate for bureaucratic or political reasons. Regulators may be more likely to rely on bailouts, which induce moral hazard.

Although we have focused principally on the exemption of QFCs from the stay, the associated safe harbor also shelters QFC counterparties from bankruptcy rules against "preferences." Under the ordinary preference provision, creditors are required to disgorge any payments or other transfers they receive during the ninety days before a debtor files for bankruptcy. ${ }^{24}$ (The preference provision is subject to a variety of exclusions, one of which is noted below; the others are not relevant for present purposes). The counterparties to a debtor's QFCs are exempt from the preference provision; they can retain any payments or collateral they have received on the eve of bankruptcy. ${ }^{25}$ The preference provision that applies to other creditors has traditionally been justified as 1) promoting the equal treatment of similarly situated creditors; and 2) as discouraging creditors from grabbing essential assets when a debtor is in financial difficulty. With QFCs, this exemption from the preferences provision has a potential chilling effect on the filing incentives of managers that looms as large as concerns about equal treatment or the antigrabbing concerns of preference law. If the normal preference provision applied, the debtor could retrieve any unusual payments or new collateral that it gave to a counterparty on the eve of bankruptcy, which would provide further incentive to file in some instances. (We say "unusual" because payments in the "ordinary course" are generally protected. ${ }^{26}$ ) If counterparties are exempt from the automatic stay, by contrast, the debtor does not have this option.

The collapse of AIG in 2008 vividly illustrates the implications. After AIG was downgraded, its previously uncollateralized derivatives counterparties began demanding that it post collateral. Goldman Sachs, for instance, made aggressive demands for collateral, leading to valuation disputes between it and AIG. These massive collateral transfers on the eve of AIG's collapse are classic examples of the kind of preferential transfer that could, absent the safe harbor for QFCs, be retrieved if the debtor filed for bankruptcy. Absent the exemption for QFCs, the ability to retrieve this collateral would have given AIG's managers a strong incentive to file for bankruptcy as its fortunes deteriorated. Because Goldman and other counterparties were exempt from the normal preference rules, making recovery of the collateral considerably less likely, AIG's managers had much less incentive to use bankruptcy.

Although the costs of the safe harbors for repos and derivatives are considerable, they also bring some sizeable benefits. The first is a reduction of the incentives of repo and derivatives counterparties to "run" as soon as the debtor's

2411 U.S.C. $\S 547(b)$.

2511 U.S.C. $\S 546(\mathrm{e}) \&(\mathrm{f})$.

2611 U.S.C. $§ 547$ (c)(2). 
financial condition is suspect, accelerating a default or even causing a self-fulfilling expectation of default that need not otherwise occur. Even with the safe-harbor protection afforded by current law, QFC counterparties have demonstrated a tendency to run from a weakening debtor. This was the case with the failures of Bear Stearns and Lehman. ${ }^{27}$ Absent the stay exemption, counterparties would have an added incentive to pull out at the first sign of trouble, lest their contracts with the debtor be tied up in a bankruptcy or other failure resolution process. By giving counterparties greater flexibility to exit even after the debtor files for bankruptcy, a safe harbor for QFCs is likely to reduce the counterparties' incentives to run on the eve of bankruptcy. It is important to recognize that runs are not always undesirable. If a firm is insolvent and destined to fail, early intervention is likely to be preferable to delay, particularly if it reduces insolvency costs. In this context, a "run" can be seen as beneficial monitoring. But if the debtor is solvent, or if sudden exit will produce destructive systemic consequences, runs are undesirable. The exemption from the stay (and preference law) may make these undesirable runs less likely.

A second benefit of the safe harbor is that it increases the ability of a firm to rely on critical hedges. Dealer banks and certain other large financial institutions make effective use of high-volume and complex dynamic hedging strategies involving derivatives and repos. The imposition of an automatic stay, in the event that a financial institution's counterparty undergoes some form of failure resolution, could significantly impair the risk management of the financial institution, or even destabilize the financial institution. Under a stay, derivatives and repos with the debtor would be in limbo until the debtor decides which contracts to assume and which to reject. This form of destabilization entails financial distress costs for the firm itself and additional costs to the economy at large if the firm is systemically important.

To consider this effect, suppose that a firm has a hedging transaction with a failing debtor. A stay might place the hedge in a precarious condition. Most obviously, a stay would allow the debtor to reject a hedging QFC whose gains have already offset losses for the counterparty. The very purpose of a hedge is to lower distress costs. A rejected QFC could therefore cause the counterparty to immediately experience distress costs. Further, the failed debtor's counterparty might be reluctant or unable to obtain a replacement hedge before it knows whether the debtor intends to assume the existing hedge. If a new "replacement" hedge is put in place and if it eventually turns out that the original hedge is assumed by the debtor, the combined effect of double hedging is about as risky as having no hedge at all. Conversely, if a new hedge is not taken, the counterparty might find itself unhedged

\footnotetext{
27 See Anton Valukas, "Lehman Brothers Holdings Inc. Chapter 11 Proceedings Examiner's Report," Volume 4, 2010, D. Duffie, op. cit., as well as Copeland, Duffie, Martin, and McLaughlin (2011), op. cit. We note that derivatives contracts with a weakening counterparty can often be exited via novation to a new counterparty. A market participant could refuse to become the new counterparty, given the associated exposure to the failing original party.
} 
if the debtor decides to reject the contract. An exemption from the stay clarifies this situation, thus reducing risk. This lowers the potential distress costs of counterparties to the debtor, and for the same reason may lower systemic risk. Conversely, as we have already argued, an unlimited automatic stay on QFCs would likely lower the sheer volume of OTC derivatives and repos that are used in practice, eliminating much of the benefit of the improved performance of QFCs at failure that the safe harbor allows.

Because of the safe harbor, counterparties terminated roughly 700,000 of Lehman's derivatives when it filed for bankruptcy. As explained by Summe (2011), these terminations were processed without significant systemic knock-on effects. Similarly, Lehman's safe-harbored repos terminated as they matured with only moderate counterparty default losses. In the event that a debtor cannot perform at maturity, the repo counterparty is protected by its safe-harbored ability to liquidate its collateral.

Finally, safe harbors from stays reduce the risk of costly delivery gridlocks in securities markets that could otherwise occur at the failure of one or more systemically important financial institutions. Suppose, for example, that a failing debtor could limit access by its repo counterparties to collateralizing securities. If those securities are "trapped" in a stay, they cannot be used for the planned purposes of the repo counterparties. These planned uses include commitments to settle new securities transactions and to return securities to the counterparties of other repo agreements. It is not unusual, for example, for the outstanding quantity of commitments to deliver a particular on-the-run issue of treasury notes to be several times the total outstanding issue size, because of the chains of repos and other forms of pledges that are often made of the same securities.

A similar argument applies to securities lending agreements. In the absence of a stay, securities deliveries that are facilitated by repos and securities lending agreements can continue unimpeded by the failure of the debtor. On the other hand, it can be argued, common knowledge of the existence of a potential stay on repos and securities lending agreements would change market practice in a way that reduces the quantity of such "fragile daisy chains" of delivery commitments, thus lowering concerns about significant delivery gridlocks. While this argument has merit, the ability to use QFCs to freely pledge and re-pledge securities generally promotes market efficiency. Indeed, central banks rely heavily on repos to promote market liquidity and to implement monetary policy. Further, as evidence of the systemic importance of the reliability of repo settlements, the U.S. securities industry has recently introduced a penalty for any failure to deliver Treasuries under a repo agreement, in order to lower the potential for costly settlement gridlocks and systemic risk. ${ }^{28}$ This failure penalty is slated to be extended to other heavily traded fixed-income securities.

\footnotetext{
${ }^{28}$ See Treasuries Markets Practices Group, "Frequently Asked Questions: TMPG Fails Charge," September 23, 2011, where the TMPG writes: "Why does the TMPG recommend a financial charge on
} 
Tightness in the easily-found supply of a given type of security reduces the likelihood that speculators and hedgers will be able to quickly and efficiently locate these securities for useful investment purposes. ${ }^{29}$ The more liquid and active the type of security, the greater is the social benefit of reliance on the unimpeded return of repo collateral. US treasuries are at the top of the list because of the size, efficient infrastructure, and "safe-haven" status of the cash and repo markets for treasuries. Thus, a discussion of the cost-benefit tradeoff of automatic stays in repos could lead to safe-harbor policies that make a distinction among repos and securities lending agreements that is based on the importance of liquidity in the market for the underlying securities.

\section{Safe Harbors for Market Utilities}

We turn now to a consideration of the special costs and benefits of stays on central market utilities for QFCs, such as repo clearing banks and OTC derivatives central clearing counterparties (CCPs).

By "clearing" a derivatives contract, a CCP, also known as a "clearinghouse," becomes the counterparty to each of the two original participants to the contract. That is, the CCP becomes the seller to each buyer, and the buyer to each seller. The main purpose of clearing is to insulate the original counterparties from counterparty default risk. The Dodd-Frank Act requires, with some exceptions, the central clearing of "standard" derivatives. ${ }^{30}$ Roughly speaking, a "standard" derivative is one that is sufficiently liquidly traded to be safely and efficiently cleared. Once the Commodity Futures Trading Commission (CFTC) and the Securities and Exchange Commission (SEC) interpret and implement this clearing requirement, some CCPs are expected to be extremely large holders of OTC derivatives, and to have large bilateral positions with essentially all major market participants. As a result, the question of whether and how stays should apply to a clearinghouse is now a crucial part of the equation.

Analogously, a single tri-party repo clearing bank such as JP Morgan Chase and Bank of New York Mellon can have an intra-day book of repo positions

settlement fails? Persistent elevated fail levels create market inefficiencies, increase credit risk for market participants and heighten overall systemic risk. In higher rate environments, the time value of money that is lost when delivery is not made as contracted provides an incentive to sellers to deliver bonds as agreed. Given that this incentive is smaller in low short-term rate environments, sellers are less sensitive to the timeliness of delivery. The TMPG recommends a financial charge to provide an incentive to sellers to deliver securities in a timely fashion and to therefore reduce overall fail levels."

${ }^{29}$ See D. Duffie, N. Garleanu, and L. H. Pedersen, "Securities Lending, Shorting, and Pricing," Journal of Financial Economics 2002, Volume 66: 307-339.

30 Under Dodd-Frank Act § 723, the CFTC and SEC are instructed to review swaps and to determine which must be cleared. Exemptions will apply to certain market participants and types of trades. 
representing a large fraction of the entire stock of important classes of fixed-income securities. Although ongoing reform of the tri-party repo market is likely to significantly lower the participation of clearing banks as direct repo counterparties, there remain other central repo market utilities, such as the Fixed Income Clearing Corporation, Euroclear, and Clearstream. The central clearing of repos could also emerge in a significant way.

A standard bankruptcy stay on the QFCs of these sorts of central market utilities could trigger significant damage to the financial system. The situation could be compared to what might have easily happened following the notorious events at the World Trade Center in New York on September 11, 2001. As reported by Ingber (2011), ${ }^{31}$ central market utilities for repos, including the Government Securities Clearing Corporation and the two main clearing banks, JP Morgan Chase and Bank of New York Mellon, were significantly incapacitated. Only extreme and highly discretionary human efforts averted a catastrophic market gridlock in the delivery of needed securities. Absent these efforts, many firms participating in these markets might have collapsed. In the end, there were approximately 2,000 failures to deliver promised securities, valued at about $\$ 96$ billion.

Although a resolution authority could arrange for a failing debtor's repos or OTC derivatives to be "bridged to safety," and the contracts could be assumed in a bankruptcy, any uncertainty among market participants about the resolve and ability to do so quickly and effectively could lead to extreme and unsettling market behavior.

The applicability of the stay to central market utilities is relevant in two different contexts: in the event that one or more of the large counterparties to the central market utility default, and in the event that the central utility itself defaults.

We first consider the case of default by a member of a derivatives clearinghouse. If such a debtor is put into resolution under Title II of Dodd-Frank, the clearinghouse is protected from the effects of resolution in several important respects. The receiver is explicitly required to continue to honor the debtor's margin and other obligations to the extent possible, for instance, and the CCP can terminate the QFC or exercise its other contractual rights if the receiver fails to do so. ${ }^{32}$ The clearinghouse does, however, face one major restriction: The CCP, like other counterparties, is subject to the provision that delays the exercise of termination rights until 5 p.m. on the day after the resolution is initiated. ${ }^{33}$ The clearinghouse could insist on adequate margin during this period, but could not terminate unless the receiver fails to provide it. If the failing member's derivatives

\footnotetext{
${ }^{31}$ See J. Ingber, Resurrecting the Street: How U.S. Markets Prevailed After 9/11, self-published, 2011.

32 Dodd-Frank Act $\S 210(\mathrm{c})(8)(\mathrm{G})$. In addition, if the receiver transfers a cleared derivative, the clearinghouse is not required to accept the transferee as a member of the clearinghouse. Dodd-Frank Act $\S 210(c)(9)(C)$.

33 Dodd-Frank Act $\S 210(C)(10)(B)$.
} 
are bridged by the FDIC, they remain "alive" and unterminated, provided the CCP accepts the assignment to the bridge. ${ }^{34}$

Merely a short delay in the effective treatment of a failed clearing member's positions could be important in a setting of heightened market uncertainty. Even unfounded suspicions that a large CCP could be destabilized by its inability to quickly and efficiently terminate or transfer the derivatives of a large failing member could lead to extreme systemic risk. Under current CPSS-IOSCO standards, the default management plan of a CCP is to be designed so as to safely handle the failure of its single largest clearing member. ${ }^{35}$ Under this single-failure standard, there is little tolerance for unanticipated losses to other clearing members.

In order to mitigate some of the risks of a delay that might be induced by a stay, the CCP could, before the expiration of the stay, begin to plan for the termination or redistribution of the derivatives contracts that it holds with its failed member. ${ }^{36}$ For example, the default management plan of ICE Trust, currently the largest CCP for credit default swaps, is based on an auction in which surviving members make bids and offers for the failed member's contracts. The auction could be conducted after one day has passed, if the FDIC has done nothing by then. The CCP could potentially call off the auction if the FDIC has assigned the derivatives to a bridge institution. Presuming no legal impediment, the CCP could even hold such an auction during the stay period, but with the stipulation that the executions of the auction trades are contingent on the expiration of the stay without an assignment action by the FDIC. Because the FDIC "stay" is a restriction on termination rather than a true stay, a contingent auction seems unlikely to violate the Dodd-Frank resolution rules. Conveniently, the FDIC is required to treat each failing member's derivatives positions with the CCP in an all-or-none fashion.

Clearinghouses are subject to the same rules as other parties with respect to QFCs in bankruptcy. Because of the safe harbors from the stay and from bankruptcy's anti-ipso-facto provisions, the clearinghouse could immediately terminate the derivatives (as long as it does so relatively promptly) ${ }^{37}$ and hold or sell any collateral of a clearing member who has filed for bankruptcy. For example, the CME clearinghouse liquidated its exchange-traded derivatives positions with

\footnotetext{
${ }^{34}$ The Dodd-Frank Act, $\S 210$ (c) (9) (C), gives the CCP the right not to accept the assignment.

${ }^{35}$ See Committee on Payment and Settlement Systems, Technical Committee of the International Organization of Securities Commissions, "Recommendations for Central Counterparties," Consultative Report, March 2004, Bank for International Settlements. ${ }^{36}$ Some CCPs manage the failure of a clearing member through termination settlement of the positions of the failing member, rather than redistribution of the "live" positions to surviving members. Termination, however, implies that non-defaulting members who suffer unexpected and involuntary termination of their positions may suddenly be left without needed hedges. This could be destabilizing.

37 In the Lehman case, the bankruptcy judge held that counterparties who delayed termination until months after bankruptcy was filed had waived their right to invoke the safe harbor from the automatic stay. [cite Metavante].
} 
Lehman rapidly, although not entirely without controversy. ${ }^{38}$ The clearinghouse could not, however, unilaterally insist on margin adjustments. The exemptions from the stay and related provisions cover only the "exercise of any contractual right ... to cause the liquidation, termination, or acceleration" of QFC agreements, "or to offset or net out any termination values or payment amounts." 39 The clearinghouse would therefore need to seek court approval of any requests for new margin. The clearinghouse also would be stayed from any efforts to collect any uncollateralized obligations that remained after netting and disposition of its collateral.

The second possibility is that a clearinghouse itself, rather than one of its members, becomes financially distressed. Here, although the formal rules are similar, different factors may come into play. The definition of "financial company" in the Dodd-Frank Act explicitly includes clearing agencies, ${ }^{40}$ which means that a clearinghouse can be put in Title II resolution if regulators make the appropriate determinations. As with the resolution of other financial companies, margin and other obligations presumably would continue to apply. Counterparties would be subject to the one-plus day delay in exercising their termination rights. ${ }^{41}$ If a clearinghouse files for bankruptcy, on the other hand, counterparties of the clearinghouse would be permitted to terminate their contracts and take other steps to collect what they are owed by the CCP, as discussed earlier. Counterparties would, however, be required to seek court approval before taking any other actions, such as efforts to collect any uncollateralized obligations that remain after terminating a contract.

Although the formal rules are similar, the failure of a clearinghouse could pose particularly difficult issues for the resolution process. The danger of a run on a troubled clearinghouse exists because the first counterparties to terminate their contracts would likely be paid in full, whereas those that delay might be appreciably more exposed. ${ }^{42}$

The danger of a run on a CCP might be exacerbated by "interoperability" among CCPs, by which market participants have the option to clear a given derivatives contract in any of a set of related CCPs. Interoperability allows two market participants to enter a trade with each other and then clear the trade with two different CCPs. The two interoperating CCPs would in this case have a master clearing agreement that allows them to share collateral posted by their respective clearing members. ${ }^{43}$ Given the requirement to clear, the absence of interoperating

\footnotetext{
${ }^{38}$ See the Lehman Examiners' Report, by Anton Valukas, Volume IV.

39 See, e.g., 11 U.S.C. $\$ 560$ (swaps).

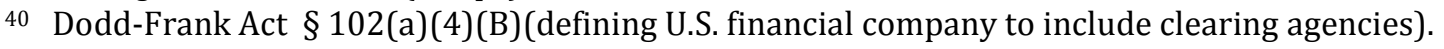
Clearing agencies singled out by the Federal Reserve as systemically important would qualify as Fedsupervised financial companies under Dodd-Frank Act § 102(a)(4)(D).

41 Dodd-Frank Act $\S 210(C)(10)(B)$.

42 This is one of the points made in Julia Lees Allen, Note, Derivatives Clearinghouses and Systemic Risk: A Bankruptcy and Dodd-Frank Analysis, 64 STAN. L. REV. (forthcoming 2012).

${ }^{43}$ See J. Maegerle and T. Nellen. 2011. "Interoperability Between Central Counterparties."
} 
CCPs to whom clearing members can quickly "port" their positions could thus limit the potential for a run. Alternatively, with a stay, a run could be stopped once the failure resolution process or bankruptcy is initiated. Currently, there are no interoperability agreements among CCPs for over-the-counter derivatives.

Currently, and probably for at least a few more years, JPMorgan, Bank of America, Goldman Sachs, Citibank, and Morgan Stanley hold a greater volume of derivatives, and far more complex derivatives, than most or all CCPs. The challenge faced by the FDIC in resolving the derivatives of a major dealer is thus currently greater than that for any CCP. This is also so because the legal and financial complexity of safely disentangling the QFCs from a failing financial firm would be much greater for a large global dealer bank than for a dedicated central market utility such as a CCP. The concept behind the "living wills" provision of Dodd Frank may help eventually, but the actual ability to safely handle the QFCs of a large dealer bank under a failure-resolution plan currently lags the concept, as emphasized by Summe (2011). The number of entities who have OTC derivatives with a large dealer bank is enormous in comparison with a CCP.

\section{Repos: Our Joint Policy Conclusion}

Although the two of us tend to give somewhat different weights to the costs and benefits that we have described, we agree that these are the most important factors in assessing the usefulness of safe harbors. We also agree on one major piece of the puzzle: the basic treatment of repos. In our view, this treatment turns on the distinction between repos that are collateralized by highly liquid securities, on the one hand, and repos that are collateralized by less liquid kinds of assets.

The value of a failing debtor's estate is not significantly enhanced by the ability to stay a repo counterparty's access to liquid collateralizing securities, such as treasuries. Stays are designed to enhance the value of a debtor's estate through continued access to the sorts of assets or services that either are critical to ongoing business operations or to lowering frictional liquidation costs. Access to marketable securities might give the debtor a source of liquidity, which is of course essential for a financial institution, but this is the purpose of debtor-in-possession (DIP) financing. Indeed, if the failed debtor needs certain liquid securities, they can by definition be purchased quickly and at low frictional costs using DIP financing. Although DIP financing is not a perfect substitute for continued access to the securities, since it must be bargained for and then approved by a court, a repo counterparty could not be forced to continue to lend to the debtor, even without a safe harbor. Under current bankruptcy law, lending contracts are automatically terminated when the debtor files for bankruptcy, and a promise to make a loan (defined as a "financial accommodation") cannot be enforced by the debtor. ${ }^{44} \mathrm{~A}$ 
court would therefore be likely to lift the stay and to permit a secured party that is secured by liquid assets to sell the assets, or at the least to require that the secured party be fully protected. ${ }^{45}$ Because liquid marketable securities are by definition easily converted to cash, and vice versa, there is no reason to delay a counterparty's access to them.

In summary, the more liquid is the market for a class of securities, the greater is the expected efficiency gain of that market's continued reliance for liquidity on repo and securities lending safe harbors, and the lower is the likely benefit to failing debtors of a potential stay on QFCs backed by that class of securities. Because of this, Skeel \& Jackson (2011) conclude that repos of liquid securities should be deemed to be breached upon the bankruptcy of a debtor, giving counterparties immediate access to the pledged securities. This is effectively the treatment afforded by a QFC safe harbor. We both agree with this conclusion, which is also reflected in the proposed "Chapter 14" special bankruptcy provisions of Jackson (2011).

A similar analysis would apply to the application of ordinary preference law to repos. In theory, payments or adjustments to a repo during the ninety days before bankruptcy would be subject to attack by the debtor or a trustee in bankruptcy as preferences. In practice, the danger to a repo counterparty of being forced to disgorge prebankruptcy payments or adjustments is limited. So long as the repo securities are worth more than the price at which the debtor is obligated to buy them back, any transfers by the debtor to a repo buyer would be protected. Payments to a fully secured creditor are not treated as preferential. This is based on the theory that the creditor would be paid in full even if no payments were made prior to bankruptcy, and thus is not being "preferred." 46 Repo buyers are essentially fully secured creditors. In other work, Skeel and Jackson (2011) have advocated that bankruptcy's "two point net improvement" rule be applied to repos and derivatives, in order to remove any lingering uncertainty. Under this rule, which is currently used for loans collateralized by inventory or accounts receivable, the counterparty would be protected so long as it was no more fully protected as of bankruptcy than it was 90 days before bankruptcy (or at the time the loan was made, if it was made less than 90 days before bankruptcy). ${ }^{47}$ The same principle could be extended to repos. In our view, it makes sense to provide this protection to all repos, even those that involve relatively illiquid collateral.

To some extent, the safe-harbor treatment (for most purposes) of repos collateralized by liquid marketable securities, as opposed to less liquid assets, is reflected in the current bankruptcy code, which does not treat certain "less liquid" forms of repos as qualifying for the safe harbor. Under the original definition, as

4511 U.S.C. § 362(d)(1)(providing relief from the stay "for cause," including a lack of adequate protection).

46 The secured creditor therefore does not receive "more than" it would have received absent the transfer, which means that 11 U.S.C. $§ 547(b)(5)$ is not met.

4711 U.S.C. $§ 547$ (c)(5). 
adopted in 1984, only repos collateralized by treasury bills and other cash-like securities were protected by the safe harbor. In 2005, the safe harbor for repurchase agreements under Section 101 of the Bankruptcy Code was expanded to include repos involving "mortgage related securities" as well as "mortgage loans" and "interests in mortgage related securities or mortgage loans." 48 The mortgagerelated securities that were added to the definition in 2005 are often comparatively illiquid, as the fallout from the 2008 financial crisis has made clear. The safe harbor further extends, under Section 741 of the Bankruptcy Code, to a range of transactions known as "securities contracts" that effectively cover most of the remaining forms of "repos" currently conducted by dealer banks. We believe that this historical expansion of the repo safe harbor to include repos collateralized by less liquid securities was probably excessive, at least from the viewpoint of social costs.

\section{Darrell's Policy View for OTC Derivatives Stays}

I believe that the safe harbor should be eliminated for all uncleared derivatives. The transition to the loss of safe harbor for uncleared derivatives should be delayed for several years from its announcement in order to allow time for market participants to adjust their balance sheets and risk-management methodologies to an environment that includes stays on these contracts. There should be a comprehensive safe-harbor for those derivatives that have been cleared by a failed market participant (other than a CCP) under a regulatory standard for clearing, such as Dodd-Frank in the U.S.

This separate treatment of cleared and uncleared derivatives strikes a balance between costs and benefits, one that reaps the net benefits of reliance on a safe harbor where they matter the most, which is for large liquid classes of derivatives. This is basically the policy suggested by Tuckman, ${ }^{49}$ who believes however that a CCP is not an appropriate approach to clearing. This separated approach to stay exemptions is only effective if a significant fraction of derivatives are cleared, and if the most liquid derivatives are those that are cleared. I think those conditions are likely to apply after some time has passed. This policy has the likely side effect of encouraging the use of clearing. While increased use of clearing is likely to lower systemic risk, it is too early to be completely confident of that.

For the case of a failed CCP, as opposed to a failed clearing member, the costbenefit tradeoff for stay exemptions is more complex, and depends in part on the potential for a run on a CCP. It is reasonable to suppose that the class of cleared

4811 U.S.C. § 101(47)(defining "repurchase agreement").

${ }^{49}$ See Tuckman, Bruce "Amending Safe Harbors to Reduce Systemic Risk in OTC Derivatives Markets,

"Center for Financial Stability, Working Paper, April 22, 2010. 
derivatives largely coincides with the class of derivatives that is legally required to be cleared. If so, it would usually be illegal to run from a CCP to a counterparty that is not a CCP. There could, however, be a rush to enter offsetting trades with a CCP before its failure. This would not likely destabilize a CCP that handles margins prudently, although it may lead to some disruption of related markets. After its failure, a CCP would presumably have the right to suspend the clearing of new trades, so a run via offsetting new trades can be stopped without a stay. Overall, then, the damage caused by a run on a CCP seems limited except perhaps in a situation involving interoperability, as we have explained. In the absence of a stay, I would propose a regulatory prohibition of the use of interoperability to novate derivatives from one CCP to another after the failure of one of the two CCPs, except as expressly permitted by the primary regulator of the failed CCP.

Aside from the effect of a run, one should consider the contagious effect of the failure of a CCP on its clearing members, and how that impact might be mitigated by a stay. By the very fact of its failure, a CCP is unable meet its obligations to its clearing members in a timely fashion, whether or not there is a stay. How could a stay reduce the associated damage? Under the stay that would be accompanied by a Title-II resolution of the CCP, the FDIC could use its discretion to separate clearing members into three groups: (1) those whose derivatives should be transferred (without recourse by the transferee) to a reliable "bridge CCP," (2) those whose derivatives should be allowed to terminate or be assigned to another clearing member under the normal contractual default-management process of the CCP, and (3) those whose derivatives should be rejected. If this discretion is used effectively by the FDIC, the stay could be a powerful mitigant of systemic damage caused by the failure of a CCP, including the total distress costs to clearing members. The main disadvantages would be any inefficient use of this power, and the effect of uncertainty among clearing members regarding how the discretion of the FDIC would be applied.

Under the new "Chapter 14" of the bankruptcy law that has been proposed by Jackson (2011), whether or not under a stay, a CCP that has filed for bankruptcy would provide some cash liquidity to clearing members against derivatives claims that are systemically important. This provision of liquidity would be subject to clawbacks described by Jackson, and could be funded through debtor-in-possession financing. During the stay proposed by Jackson, the debtor could also decide which clearing members would have their derivatives terminated or re-assigned as stipulated under the original derivatives contracts, and which clearing members would have their derivatives rejected.

Absent a stay of derivatives with a failed CCP, the attempt to contractually terminate or re-assign the derivatives of the CCP, nearly all of them simultaneously, would likely lead to indiscriminant and potentially uncontrollable damage to many clearing members. Confusion and uncertainty could be heightened, among clearing members and more broadly. The contagion induced by such an unwind is unpredictable. 
The situation faced by a failed CCP can be compared to the failure of a major dealer bank, several of which currently have vastly more derivatives than any CCP, including more complex derivatives, and with more counterparties. With Lehman's bankruptcy, the systemic damage caused by the unstayed treatment of its OTC derivatives was manageable without heavy systemic damage, as explained by Summe (2011), but this could in part be due to the other resources available to Lehman's estate. Given the absence of a stay, for example, Lehman's unsecured bond creditors offered a substantial loss-absorbing buffer to the derivatives claimants that would not be present for a failed CCP whose "waterfall" of margins, defaultguarantee funds, and capital have, by the definition of failure, been fully exhausted. ${ }^{50}$ That is, there is likely to be no liquid resources available to a CCP once it has failed. The liquidity support of the Federal Reserve provided under Title VIII of Dodd-Frank is designed to offer cash loans collateralized by the non-cash resources of the CCP. It might be only after cash liquidity supplied by the Fed has been exhausted that the CCP would fail (if it fails at all) and any stay could begin.

A decision by a government to "bail out" a CCP, providing it with new capital (as opposed to liquidity backed by the assets of the CCP), could mitigate systemic damage either before or after the failure of a CCP. Such a bailout, however, could not be relied upon, especially in the prevailing political environment. In any case, reliance on this form of support raises moral hazard. It is doubtful that the costbenefit analysis of stays for failed CCPs should place much weight, for policy purposes, on government bailouts.

Overall, I believe that it is prudent, pending further analysis, to allow a brief stay of the derivatives held by a failed CCP. The duration of the stay should be only long enough to allow the effective exercise of the powers allowed under the stay, assuming the existence of an efficient infrastructure for this purpose. For example, the stay durations of Dodd-Frank's Title-II, one day, and of Jackson's Chapter 14, three days, seem reasonable. These stays would be too brief to make effective use of the stays absent effective information technology designed for the purpose of quickly exercising the powers allowed by the stay.

\section{David's Policy View}

Although I prefer a short, across-the-board stay on derivatives in bankruptcy, as I will detail below, I quite like your proposal for a stay on uncleared derivatives. Such a stay would reach the derivatives that most need to be stayed; and as you note, the differential treatment of cleared and uncleared derivatives would create at least a small additional incentive to use cleared derivatives. I also agree that the change in bankruptcy treatment should be phased in over time, to minimize the disruption of shifting to the new regime. Overall, I would be a much happier person if you were

${ }^{50}$ The default-management process of a CCP is outlined in the appendix of D. Duffie (2010), op. cit. 
appointed as derivatives czar, and given the authority to determine the rules for regulation of derivatives in bankruptcy and elsewhere.

I nevertheless believe that a short stay should be applied to all derivatives, cleared as well as uncleared. To be sure, several of the principal dangers of unstayed derivatives are most pronounced with derivatives that are not cleared. The risk of firesales may be greater, for instance, since uncleared derivatives are more likely to be collateralized by illiquid collateral. But the underlyings of cleared derivatives may also be illiquid, and even seemingly liquid collateral can also pose a risk of firesales in the midst of a financial crisis. Similarly, a stay on derivatives may only give managers an incentive to file for bankruptcy rather than waiting for regulators to intervene if it (and ordinary preference rules) applies to cleared derivatives, since most dealers' derivatives portfolios will include large amounts of cleared derivatives.

Oddly enough, if Dodd-Frank achieves its objective of moving a large majority of derivatives to CCPs, imposing a stay on cleared derivatives may be more rather than less important. The likelihood that a substantial portion of a dealer's cleared derivatives will involve illiquid and difficult-to-value collateral will be much higher if there is a massive shift to clearing, for instance, and managers would have little incentive to prepare for bankruptcy if most of their derivatives portfolio consisted of cleared and therefore unstayed derivatives. To minimize disruption, I believe the stay should be short- Jackson and I have advocated a three-day stay elsewherebut that it should apply to all derivatives. For similar reasons, I also believe that it should apply to the clearing bank in tri-party repo arrangements.

If the stay did indeed include cleared derivatives, lawmakers would need to decide whether it should apply to the CCP as well as the debtor's counterparties, or just to the counterparties. There is a plausible argument for exempting the CCP from the stay. A three-day stay would complicate a CCP's margin calculations, since it would need to require adequate margin not just for current values of the derivative, but also for potential changes in value up to three days into the future. But a CCP's margin calculations, under best practice, already are supposed to be enough to cover not only the normal re-margining period, but also the period necessary to unwind the position in a default scenario, which would take a few days. ${ }^{51}$ Thus, a three-day stay would not significantly alter the CCP's time horizon. , Similarly, CCPs would not be able to terminate and replace derivatives instantly, even in the absence of a stay. It would take the CCP a day or two to set up an auction to replace a debtor's derivatives positions. So long as the stay did not prevent the CCP from making preparations for the auctions, conditioned on the debtor's nonassumption of the derivatives (and I would advocate that the stay be defined to explicitly permit these kinds of preparations), I believe the effect of a stay on the CCP would therefore be limited enough to be manageable.

51 See Committee on Payment and Settlement Systems, Technical Committee of the International Organization of Securities Commissions (2004) op. cit. 
The failure of the CCP itself, rather than a dealer, would pose somewhat different issues. Some of the main objectives of resolving the financial failure of dealers and other firms do not apply in the same way to a CCP. With other firms, the desire to preserve the going concern value of the business if it remains viable is an important consideration. This factor seems less central with a CCP. Limiting the potentially destructive effects of the inability to make good on large numbers of derivatives is a much more pressing consideration. In addition, it is not clear that the presence or absence of a stay would affect the CCP's managers' incentives to file for bankruptcy to nearly the same extent as with managers of a dealer or other firm.

The importance of a stay may depend on how many CCPs emerge, and whether the failing CCP has a large presence in the market. If a small CCP failed, the stay may not be essential. If a CCP of any size fails, by contrast, I think a stay would be essential, for the reasons you very persuasively detail. Neither the FDIC nor a private decision maker could effectively handle large numbers of derivatives quickly enough to prevent systemic damage in the absence of the stay. It seems likely that the market for CCPs will be sufficiently concentrated as to warrant general application of a short stay to all CCPs, as you recommend.

Overall, I differ from you only in my conclusion that the stay should apply to both cleared and uncleared derivatives. I agree that the duration of the stay should be limited, and that it should be phased in over time. In my view, the imposition of a limited stay in bankruptcy would go far toward plugging a major gap in the DoddFrank reforms.

\section{Concluding Remarks}

After an extensive dialogue, and in part because of some convergence caused by that dialogue, the respective policy views that we have described are somewhat similar. To summarize, we both believe that repos (and related QFCs such as securities lending agreements) that are backed by liquid securities should be exempted from automatic stays, or receive an effectively similar treatment. Repos backed by illiquid assets, on the other hand, should not be given this safe harbor. We both believe that uncleared derivatives should be subject to automatic stays. One of us (David) believes that stays should also apply to cleared derivatives. The other (Darrell) favors an exemption of cleared derivatives from stays, except in the case of a failure of a regulated central clearing party. Both of us believe that the period of any stay on cleared OTC derivatives should be only long enough for an efficient exercise of the debtor's rights under a stay, a few days at most. 